\title{
Dehiscent organs used for defensive behavior of kamikaze termites of the genus Ruptitermes (Termitidae, Apicotermitinae) are not glands
}

\author{
Silvana B. Poiani* ${ }^{*}$ Ana M. Costa-Leonardo \\ Departamento de Biologia, Instituto de Biociências de Rio Claro, Universidade Estadual Paulista-UNESP, Av. 24A, 1515, Bela Vista, 13.506-900 Rio Claro, SP,
} Brazil

\section{A R T I C L E I N F O}

\section{Article history:}

Received 9 December 2015

Received in revised form

22 December 2015

Accepted 28 December 2015

Available online 2 January 2016

\section{Keywords:}

Abdominal rupture

Fat body

Histochemistry

Protein

Soldierless termites

Workers

\begin{abstract}
A B S T R A C T
During Isoptera evolution, the caste of soldiers disappeared in some Apicotermitinae termites as in the Neotropical Ruptitermes. Paired dorsolateral structures located between the metathorax and abdomen of foraging workers of Ruptitermes were previously denominated dehiscent glands, and are responsible for releasing an adhesive secretion that immobilizes enemies, causing their death. In this study, we investigated the morphology of dehiscent organs of workers of Ruptitermes reconditus, Ruptitermes xanthochiton, and Ruptitermes pitan and also second instar larvae of $R$. reconditus using light, laser scanning confocal, and transmission electron microscopy. Additionally, we performed a preliminary protein analysis using SDS-PAGE to further characterize the secretion of Ruptitermes dehiscent organs. Our results showed that the dehiscent organs do not exhibit the typical characteristics of the exocrine glandular cells class I, II or III of insects, suggesting that they constitute a new type of defensive organ. Thus, the denomination dehiscent gland was not used but dehiscent organ. Dehiscent organs in larvae are formed by fat body cells. In workers, dehiscent organs are composed by compact masses of cells that accumulate a defensive secretion and are poor in organelles related to the production of secretion. Since the dehiscent organs are not glands, we hypothesize that the dehiscent organs originate from larval fat body. The defensive secretion may have been produced at younger developmental stages of worker or the defensive compounds were absorbed from food and accumulated in the worker fat body. Histochemical techniques and SDS-PAGE revealed that the secretion of Ruptitermes dehiscent organs is constituted mainly by a protein of high molecular weight ( $200 \mathrm{kDa})$. In conclusion, the dehiscent organs are extremely different from the exocrine glands of termites and other insects described until now. In fact, they seem to be a specialized fat body that is peculiar and exclusive of Ruptitermes termites.
\end{abstract}

(C) 2016 Elsevier Ltd. All rights reserved.

\section{Introduction}

Termite colonies contain apterous and alate castes. The apterous caste is composed by workers and soldiers envolved with colony labor and defense, respectively, while the alate caste is responsible for colony reproduction. The latter caste includes the king and one or more queens, responsible for egg production and maintenance of the population. All species are eusocial and have both worker and soldier castes, or only workers (Boomsma, 2009).

The occurrence of the soldier caste has an important impact in the defense system of the colony since soldiers are equipped with specific morphological adaptations in the head and powerful mandibles very useful in defense activities (Deligne et al., 1981),

\footnotetext{
* Corresponding author. Fax: +55 1935264136.

E-mail address: silbeani@gmail.com (S.B. Poiani).
}

defensive behavioral strategies (Pasteels and Bordereau, 1998), and exocrine glands that perform chemical defense. Among exocrine glands related to defense are the salivary glands (Maschwitz et al., 1972; Šobotník et al., 2010a), frontal glands (Costa-Leonardo and Kitayama, 1991), and labral glands (Šobotník et al., 2010a).

Soldierless Apicotermitinae is a taxonomic group of termites that have been received less attention in comparison with other termite taxonomic groups. In terms of species diversity and abundance, the Apicotermitinae dominate African and Neotropical rainforests, where they generally feed on soil organic fractions (Bourguignon et al., 2015a). Particularly, the genus Ruptitermes Mathews, 1977 is endemic to South America and is relatively abundant in the Cerrado ecoregion of central Brazil. Acioli and Constantino (2015) recently published a taxonomic review of this dominant Neotropical taxon in which they described nine new species of Ruptitermes, including one of the species studied in the present research. 
The soldier caste has been lost in some termite species, like all Neotropical Apicotermitinae (Sands, 1972) and some Termitinae (Ahmad, 1976; Miller, 1984). Therefore, during the process of evolution, worker caste has also developed and specialized in a variety of defensive strategies. The "kamikaze termites" are termite workers that have been named as such because they "explode" during a fight with their enemies. In fact, what really occurs is a rupture of the abdominal body wall of these individuals with release or not of a viscous-like secretion, a phenomenon known as abdominal dehiscence (Sands, 1982). This secretion rapidly turns opaque and thick when it comes into contact with air (Mill, 1984), and acts by immobilizing termite and enemy, which usually both die. When the source of the viscous secretion is glandular the altruistic suicide of termites is named autothysis (Bordereau et al., 1997).

The salivary glands were thought to be the structures responsible for, and involved in Ruptitermes bursting (Fontes, 1992; Mathews, 1977). However, Costa-Leonardo (2004), using light microscopy, verified that other organs different from salivary glands were functioning as defensive structures in some Ruptitermes species, and named them "dehiscent glands" since the secretion is released through abdominal dehiscence. This author also showed that dehiscent glands are paired structures located between the metathorax and the first abdominal segment of workers, which produce a viscous-like secretion. Later, Šobotník et al. (2012) identified a new exocrine gland responsible for producing copper-rich protein crystals with a molecular weight of $\sim 76 \mathrm{kDa}$, in workers of $\mathrm{Neo}$ capritermes taracua. These crystals react with secretions from the salivary glands, causing rupture of the body wall of these workers.

Exocrine gland cells of insects can be classified into three categories (classes I, II and III) based on their cellular structure and the way the secretion is released through the cuticle (Noirot and Quennedey, 1974, 1991; Quennedey, 1975). Additionally, it is known that class I epidermal cells are the predominant type in the adhesive glands of insects (Dettner et al., 1985). Nevertheless, the ultrastructure of dehiscent organs was never studied. Light microscopy about dehiscent organs (Costa-Leonardo, 2004) not elucidated to which class (I, II or III) the glandular cells belong. Similarly, little is known about their morphological structure. For these reasons, throughout this research, the term "dehiscent gland" (Costa-Leonardo, 2004) was not used but "dehiscent organ".

The present study investigated the morphology of dehiscent organs in termite workers belonging to three species: Ruptitermes reconditus (Silvestri, 1901), Ruptitermes xanthochiton (Mathews, 1977), and Ruptitermes pitan (Acioli and Constantino, 2015), using light, electron, and laser confocal microscopy. A preliminary protein analysis using SDS-PAGE was also performed in order to further characterize the secretion of the dehiscent organs. Our aim was to elucidate the morphology and functioning of the dehiscent organs used for the defense of Neotropical Ruptitermes, and, hence, contribute to the knowledge of the defense system of soldierless Apicotermitinae species.

\section{Material and methods}

\subsection{Insects}

Worker termites of $R$. reconditus, $R$. xanthochiton, and $R$. pitan were collected during foraging activities and second instar larvae of $R$. reconditus were collected from shallow galleries under the exit of the subterranean nests located at the campus of the Universidade Estadual Paulista (UNESP), Rio Claro, Brazil.

\subsection{Light microscopy}

\subsubsection{Total preparations.}

The dehiscent organs of four workers of $R$. reconditus were dissected in physiological solution for insects, and stained with $0.5 \%$ methylene blue. After another addition of physiological solution, the material was covered by a glass coverslip and observed under a light microscope.

\subsubsection{Histology and histochemistry}

For light microscopy, thorax and abdomen of ten workers of $R$. reconditus, $R$. xanthochiton, and $R$. pitan were isolated in buffered saline solution for insects, and fixed in $4 \%$ formaldehyde for $2 \mathrm{~h}$. Afterwards, the samples were dehydrated, embedded in Leica historesin, and placed in the same resin containing a catalyst. After resin polymerization, the blocks were cut into $4-6 \mu \mathrm{m}$ slices, mounted on histological slides, and stained with hematoxylineosin (HE) for comparative morphology, and bromophenol blue (BB) and xylidine Ponceau (XP) for protein detection. Five whole second instar larvae of $R$. reconditus were included for histology following the same procedures described above and the histological slices were stained with hematoxylin-eosin (HE).

\subsection{Laser scanning confocal microscopy}

Immunocytochemical techniques were performed for the detection of:

\subsubsection{Plasma membrane (red) and nucleus (green)}

The dehiscent organs of ten workers of $R$. reconditus and $R$. xanthochiton were dissected in $3.5 \%$ formaldehyde, incubated first with Alexa 633, and after with SYTO 11. Between each step, the organs were washed 2 times with phosphate-buffered saline (PBS) solution.

\subsubsection{Microtubules (blue) and nucleus (green)}

The dehiscent organs of five $R$. reconditus workers were dissected in $3.5 \%$ formaldehyde, immersed in $0.1 \%$ Triton $\mathrm{X} 100$, and incubated overnight in monoclonal anti-tubulin $\alpha / \beta$ (Sigma-Aldrich) diluted 1:100, inside a humid chamber. Afterwards, the organs were incubated first with Alexa 405, and finally with SYTO 11. Between each step, the organs were washed 2 times with PBS.

\subsubsection{Actin (green) and nucleus (red)}

The dehiscent organs of five workers of $R$. reconditus and $R$. pitan were dissected in $3.5 \%$ formaldehyde, immersed in $0.1 \%$ Triton X100, treated with RNAse $(10 \mathrm{mg} / \mathrm{ml})$, incubated with propidium iodide in the dark, and stained with Phalloidin-FITC (Sigma-Aldrich; 7.5 mM). Between each step, the organs were washed 2 times with PBS.

\subsubsection{Endomembrane (red) e nucleus (green)}

The dehiscent organs of five workers of $R$. reconditus were dissected in PBS, immersed in endomembrane marker, and incubated with SYTO 11.

All total preparations of dehiscent organs were analyzed under a Leica TCS SP5 II confocal laser scanning microscope. The LAS AF software (Leica) was used for image analysis.

\subsection{Transmission electron microscopy (TEM)}

The dehiscent organs of ten workers of $R$. reconditus and $R$. pitan were dissected and fixed for $48 \mathrm{~h}$ in $2.5 \%$ glutaraldehyde in $0.1 \mathrm{M}$ sodium cacodylate buffer ( $\mathrm{pH} 7.4$ ). In previous assays, we fixed the organs for 2, 4, and $24 \mathrm{~h}$ and, in all cases, the material was found 

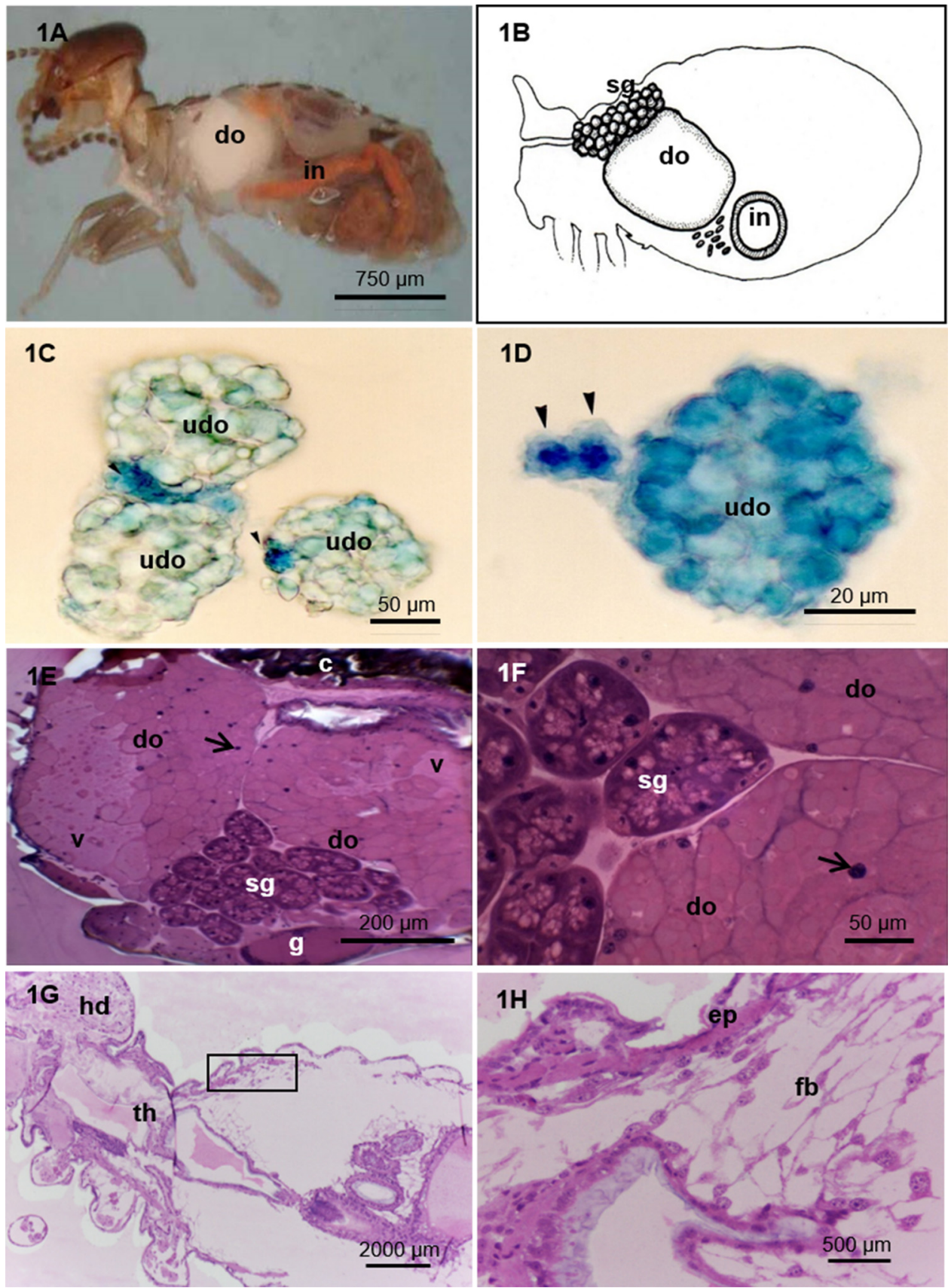

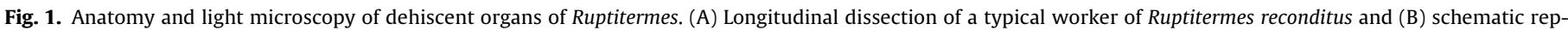

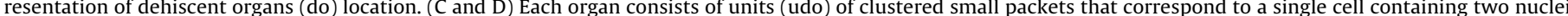

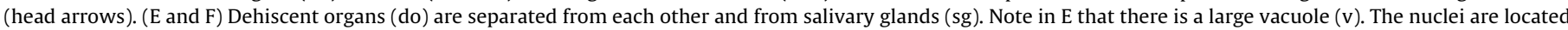

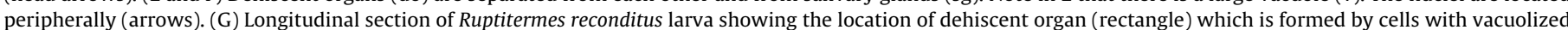

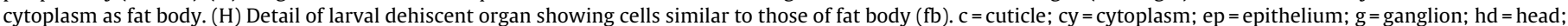
th $=$ thorax.

to be poorly preserved. Similarly, fixing the samples for $48 \mathrm{~h}$ did not seem to improve the preservation of the material. It is possible that the chemical nature of the defensive secretion hinders the penetration of the fixative and the preservation of the organ as a whole. Samples were postfixed for $1 \mathrm{~h}$ in $0.5 \%$ osmium tetroxide containing $0.8 \%$ potassium ferrocyanide in the same buffer. After washing with buffer, samples were incubated for $3 \mathrm{~h}$ in $2 \%$ tannic acid. After another wash, dehiscent organs were stained with $1 \%$ uranyl acetate in $10 \%$ ethanol for $2 \mathrm{~h}$, and dehydrated in an acetone series. Samples were then embedded in Epon-Araldite resin and the resin was polymerized in a stove at $60^{\circ} \mathrm{C}$. Sections were placed in copper grids, stained with uranyl acetate and lead citrate, and examined in a Philips transmission electron microscope (TEM).

\subsection{Protein analysis}

Fifty dehiscent organs of R. xanthochiton workers were separated in five samples (X1-X5) containing, respectively, six, seven, nine, 11 , and 17 organs. Fifteen dehiscent organs of $R$. reconditus workers were separated in two samples (R1 and R2) containing, respectively, three and nine organs. Samples containing different amounts of organs aimed to determine the minimum number of dehiscent organs required to obtain a protein concentration sufficient for pro- 

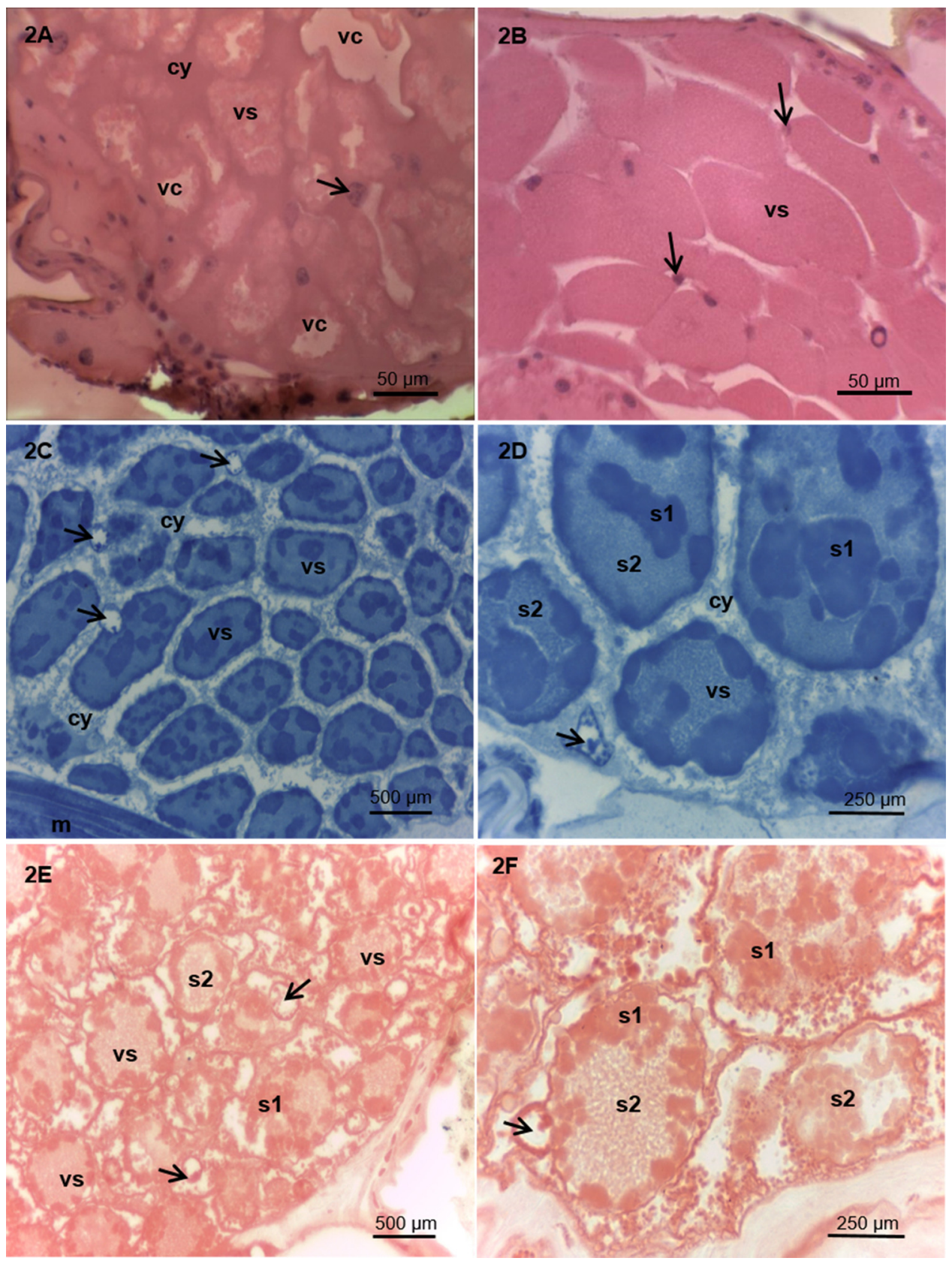

$2 \mathrm{~F}$

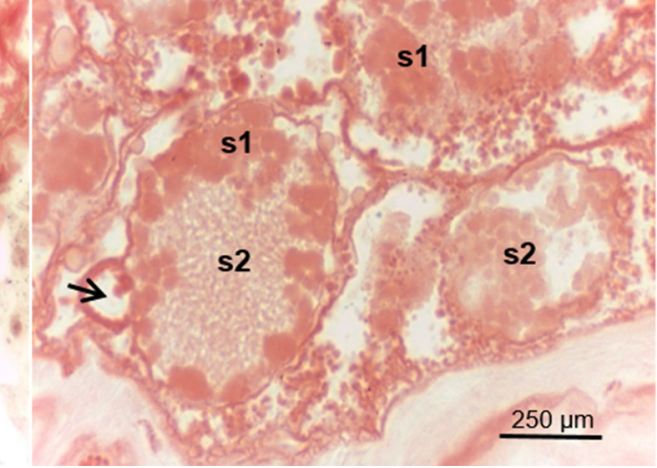

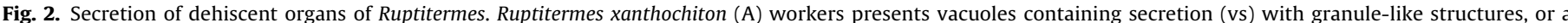

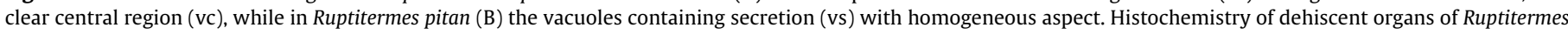

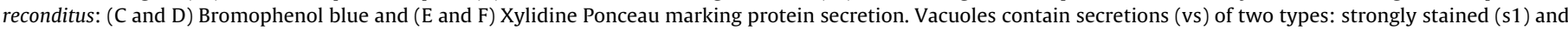
weak stained (s2). Generally, nuclei (arrows) are located next to vacuole of secretion. Ribbon of cytoplasm (cy) is involving the vacuoles.

tein separation. Dehiscent organs were dissected and homogenized in $30 \mu \mathrm{L}$ of sodium acetate buffer (SAB) $0.1 \mathrm{M}, \mathrm{pH} 5.5$, containing $1 \mu \mathrm{L}$ of protease inhibitors (Complete Mini EDTA-free; Roche, Mannheim, Germany). Aliquots of $20 \mu$ L were transferred to Eppendorf tubes, and $5 \mu \mathrm{L}$ of Laemmli buffer was added to solubilize and denature the proteins. Samples were then heated at $95^{\circ} \mathrm{C}$ for $5 \mathrm{~min}$, and applied $(20 \mu \mathrm{L})$ to $12 \%$ sodium dodecyl sulfate-polyacrylamide gel electrophoresis (SDS-PAGE). Protein concentration was determined by the method of Bradford and gels were stained with Coomassie Blue.

Samples were analyzed at the Brazilian Biosciences National Laboratory (LNBio) at the Brazilian Center for Research in Energy and Materials (CNPEM) in Campinas, São Paulo, Brazil.

\section{Results}

\subsection{Light microscopy}

\subsubsection{Total preparations}

The dehiscent organs are paired structures located on the side of the body, between metathorax and abdomen (Fig. 1A and B). Each organ consists of units of clustered small packets containing secretion. Each small packet is a single cell that may contain two nuclei (Fig. 1C and D).

\subsubsection{Histology and histochemistry}

Histological analysis showed that dehiscent organs of foraging workers are involved by a thin connective tissue and are located 
close to salivary glands, which occupy the center-ventral region (Fig. 1E). The small packets are cells whose nuclei are located peripherally. Part of dehiscent organs are vacuolized due beginning of chain reaction for exploding process (Fig. 1E). The cell cytoplasm of the dehiscent organs of $R$. reconditus workers was filled with spherical structures (Fig. 1E and F). Larvae have shown no dehiscent organ development as in foraging workers. Adipocytes present in the fat body were occupying the location where dehiscent organs should be (Fig. $1 \mathrm{G}$ and $\mathrm{H}$ ).

Secretion had different aspects among species studied. $R$. reconditus (Fig. 1F) and R. xanthochiton (Fig. 2A) presented spherical structures or a clear central region, while in $R$. pitan it was homogeneous (Fig. 2B). Histochemical for protein detection has shown strong positive marking at dehiscent organs of $R$. reconditus. Cells possess vacuoles containing two types of secretion: one that is strongly stained (s1) and the other one that is weak stained (s2) (Fig. 2C-F).

\subsection{Laser scanning confocal microscopy}

\subsubsection{Plasma membrane and nucleus}

Dehiscent organs are composed of secretory units forming a denser mass. This mass is surrounded by an outer thin membrane, probably consisting of connective tissue (Fig. 3A). In $R$. reconditus, it was possible to identify the plasma membrane of the secretory units, and the weaker central fluorescence red lines correspond to plasma membranes observed from other planes (Fig. 3B and C). Conversely, the secretory units of $R$. xanthochiton did not show these central lines (Fig. 3D). In both species, the nuclei were always on the periphery of the secretory units and contained many nucleoli. Some secretory units may have two nuclei (Fig. 3C).

\subsubsection{Actin and nucleus}

Immunocytochemistry revealed differences in actin organization in the dehiscent organs of $R$. pitan and $R$ reconditus. In $R$. pitan, actin was not labeled, whereas the canaliculi of salivary gland cells were strongly evidenced (Fig. 3E). On the other hand, in R. reconditus, actin was observed involving portions of the cytoplasm. The nuclei were large and irregular and many nucleoli were evident. It was not possible to distinguish the limits between cells (Fig. 3F and G).

\subsubsection{Endomembrane and nucleus}

The endomembranes (i.e., the organelles) of the dehiscent organ cells of $R$. reconditus were not labeled in red, while the nuclei were strongly labeled in green, and portions of cytoplasm acquired a weak labeling (Fig. 3H).

\subsubsection{Microtubules and nucleus}

Attempts were made to mark microtubules, but only greenlabeled nuclei containing many nucleoli were visualized. In addition, bacteria were found scattered within the organ (Fig. 3I).

\subsection{Transmission electron microscopy (TEM)}

Transmission electron microscopy confirmed that the dehiscent organs of $R$. reconditus and $R$. pitan consist of a cluster of cells, but the boundaries were not too evident. Muscle cells were observed in some points between the dehiscent organs and the cuticle (Fig. 4A). Cytoplasm was homogeneous and its processes were involving vacuoles and nuclei (Fig. 4A and B). Large vacuoles contained materials of different electron densities (Fig. 4A-F).

On a few occasions, we observed plasma membrane infoldings surrounding vacuoles suggesting that these may be located outside the cell, bound by the cell membrane and limiting a vacuole that will accumulate secretion (Fig. 4C-E). The infoldings were not associated with mitochondria. As the vacuoles expand, the infoldings disappear and the remaining membranes can be observed inside the vacuoles (Fig. 4E).

Nuclei were the most frequent organelle found and they were round or of irregular shape, with prominent nucleoli (Fig. 4C-E; Fig. 5A). Mitochondria (Fig. 5B) and Golgi apparatus (Fig. 5C and D) were rare, and no other organelles were observed.

Particularly in $R$. reconditus, vacuoles contained secretions of medium electron density, hereafter designated as secretion type 1 (s1), or of low electron density, hereafter designated secretion type 2 (s2) (Figs. 4, 5A, 6A ). Both types of secretion were present within the same vacuole (Figs. $4 \mathrm{~A}$ and $\mathrm{B}, 6 \mathrm{~B}$ ). In addition, some vacuoles appeared electron-transparent, without secretion (Fig. 4C-E).

The ultrastructure of the dehiscent organs of $R$. pitan differed from that of $R$. reconditus regarding the secretory granules; these were electron-dense and distributed throughout the cytoplasm. Organelles and nuclei were not observed (Fig. 6C and D).

\subsection{Protein analysis}

Protein analysis of dehiscent organs of $R$. xanthochiton and $R$. reconditus by SDS-PAGE revealed a band of approximately $200 \mathrm{kDa}$ present in all individuals, albeit stronger in X2 and X4. Other weaker bands were observed, and $\mathrm{X} 3$ presented a strong band at around $40 \mathrm{KDa}$ (Fig. 7).

\section{Discussion}

The present research attempted to fill a gap in relation to knowledge of the biology of soldierless Apicotermitinae. The dehiscent organs of Ruptitermes are important organs not only because they are used for defense but also because they are a taxonomic feature (Acioli and Constantino, 2015). This is the first study that provides results showing that defensive organs in termites are not glands but fat body specialized in defense.

The morphology of the dehiscent organs of $R$. reconditus, $R$. xanthochiton, and $R$. pitan workers is quite different from that of defensive exocrine glands previously described for termites and other insects. In fact, to our knowledge, such organs have never been described in other insects and seem to be exclusive of Ruptitermes termites. The dehiscent organs of the three termite species studied here share a similar external morphology, and the cells store but do not produce secretion in adults. However, specific features for each species were also observed.

The dehiscent organs of foraging workers are rounded structures composed by compact masses of cells that store secretion used during defensive behavior. They are paired structures but independent between themselves, and with no connection to other organs despite their close vicinity to the salivary glands. The participation of the salivary glands in the explosion process is uncertain. Chemical analysis of the compounds contained both in the dehiscent organs as those produced by the salivary glands should be identified and tested to elucidate whether salivary glands are involved in the process. According to recent studies, crystals produced by Neotropical Termitinae $N$. taracua react with hydroquinone precursors produced by parietal cells of salivary glands to form the final product that is used in defense of this termite (Bourguignon et al., 2015b; Šobotník et al., 2014).

An outer membrane of connective tissue is surrounding the mass formed by the cells and plays a fundamental role not only by holding the cells together but also as a barrier between the dehiscent organ and adjacent organs. The presence of this connective tissue prevents that the toxic secretion stored in the dehiscent organs and used in defense, leaks, and reaches other organs. The 


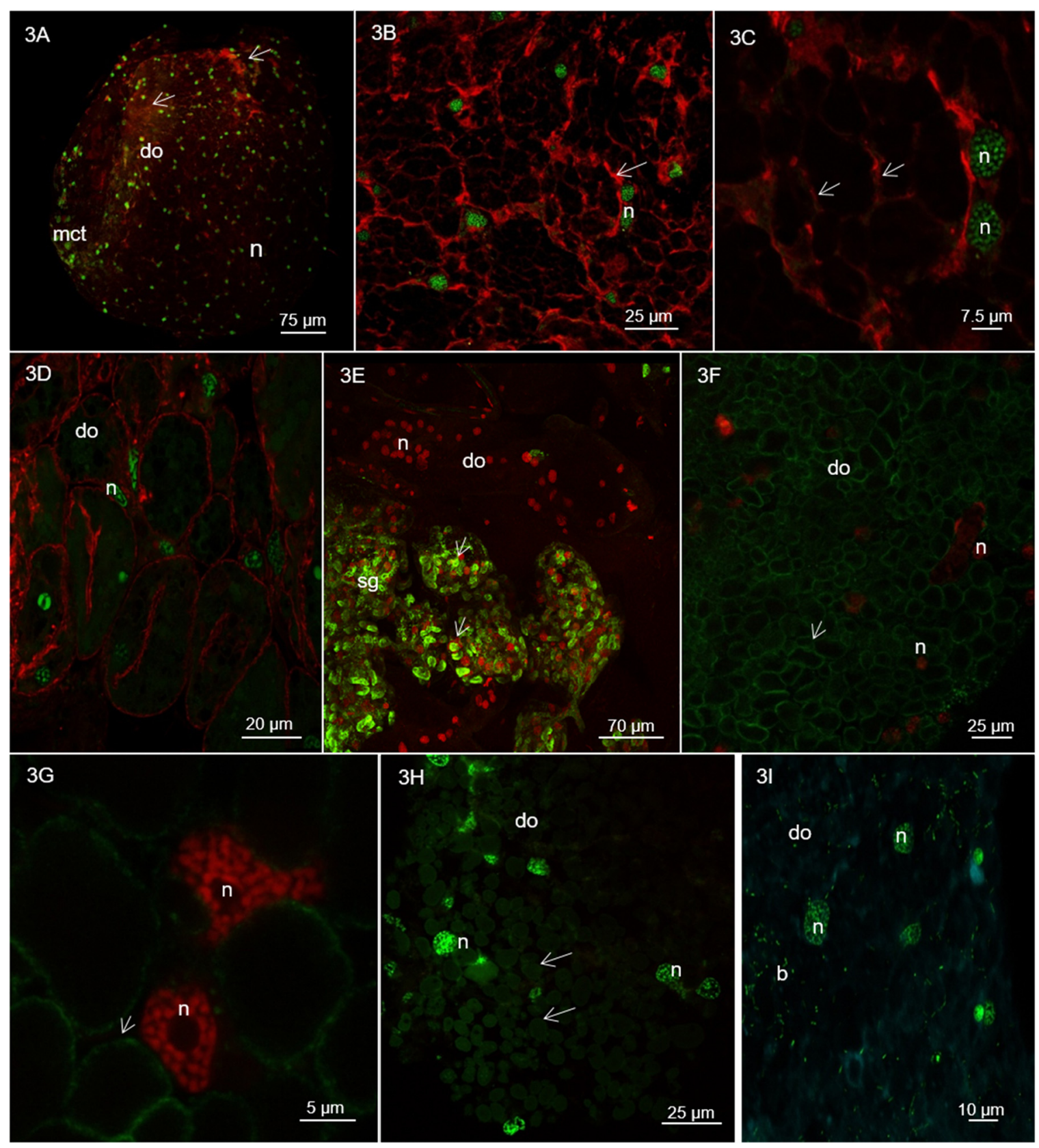

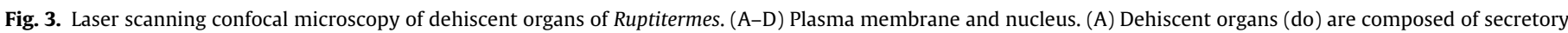

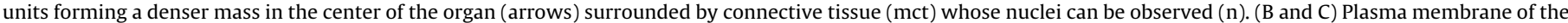

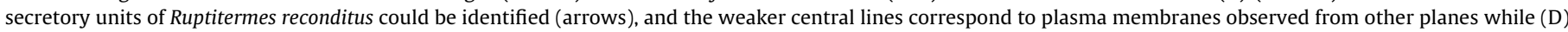

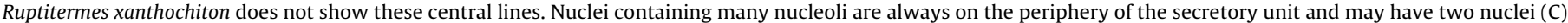

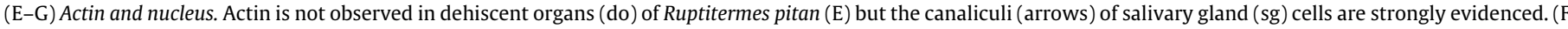

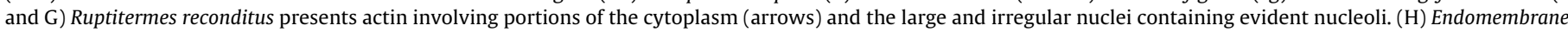

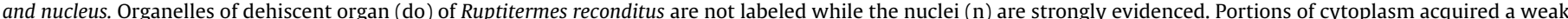

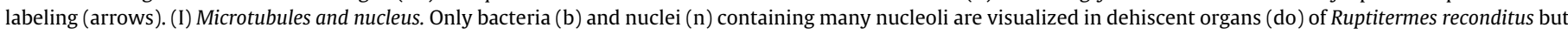
no microtubules.

musculature observed between the dehiscent organs and some points of the cuticle indicates that these muscles may play a role in breaking the body wall, and aiding the expulsion and explosion of dehiscent organs. The cell cytoplasm is homogeneous and its processes involve vacuoles and nuclei, giving the appearance of a syncytium that contributes to a quick chain reaction inside the organ when its defensive role is required.

In $R$. reconditus, large vacuoles containing secretion with different aspects may correspond: (1) to different compounds that will react when worker is fighting with enemy causing body rupture;
(2) the same compound but at different stages of maturation; (3) result of a reaction between compounds. In $R$. pitan, the secretory granules uniformly occupy the whole cytoplasm. The differences in the secretion appearance among species may indicate distinct chemical compositions, or different ages of the foraging workers.

Another feature common to the three species was that nuclei, when present, were large, peripheral, and contained many nucleoli. The peripheral position of the nuclei is most probably due to the large amount of vacuoles and secretion occupying the cell center. However, most cells did not have nucleus, suggesting that nuclei 

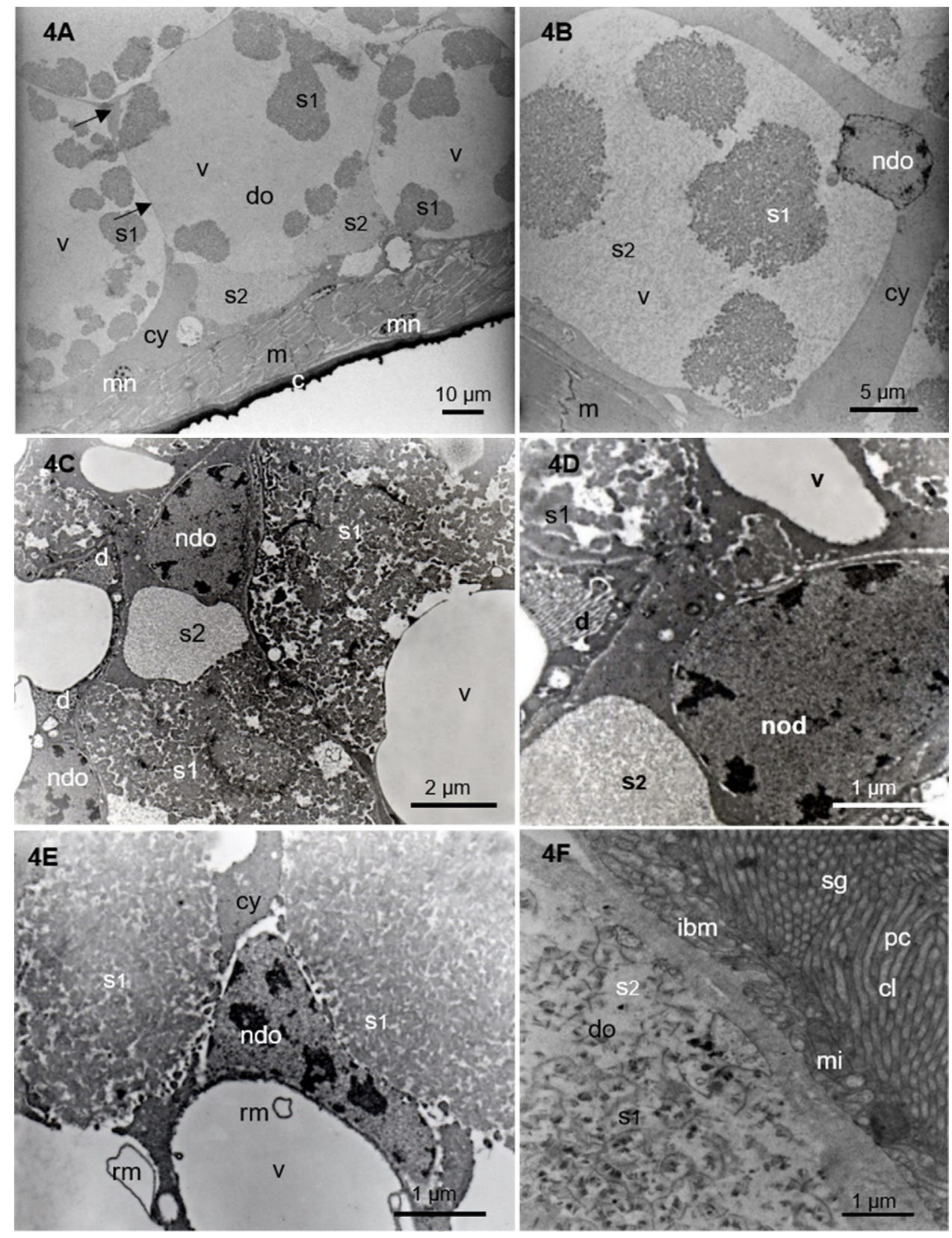

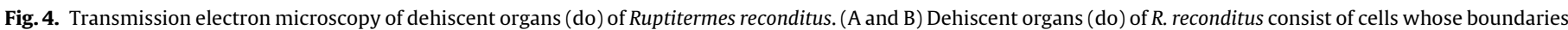

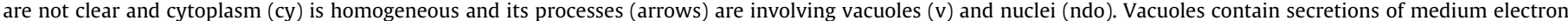

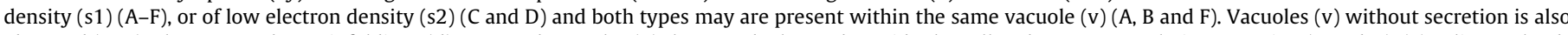

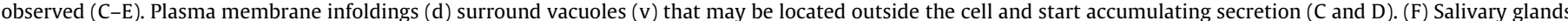

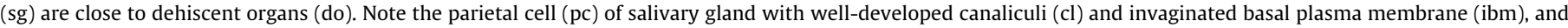

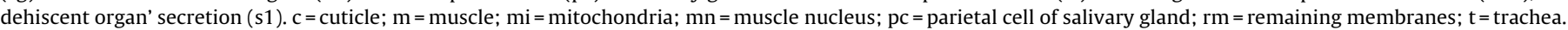

might have been lost as the cells of dehiscent organs specialized in the storage of defensive secretions. The well preserved nuclei and nucleoli indicate that that fixative solution worked properly and therefore, the description of dehiscent organs presented in this study is accurate.

Plasma membrane infoldings surrounding vacuoles were rarely observed but might mean that the cell is limiting a place outside itself where compounds are released and stored. The infoldings were not associated with mitochondria, suggesting a passive transport.

In $R$. reconditus, confocal microscopy observations showed that the cells have well-defined portions of cytoplasm surrounded by actin, suggesting that this protein could have a role in the compartmentalization of the secretion within the cells.

Epidermal glandular cells of insects can be classified into three categories based on their cellular structure and how secretion is released through the cuticle (Noirot and Quennedey, 1974, 1991; Quennedey, 1975, 1998). Class I cells are cells that constitute the epidermis and release the secretion through pores in the cuticle. Class II cells do not integrate the epidermis directly and hence the secretion must be transferred first to an epidermal cell, and then to the cuticular surface. Class III cells form glandular units composed of one or more secretory cells, with one or two cells forming the canaliculi that transport the compounds from secretory cells to the cuticle surface. Class I epidermal cells are the predominant type 

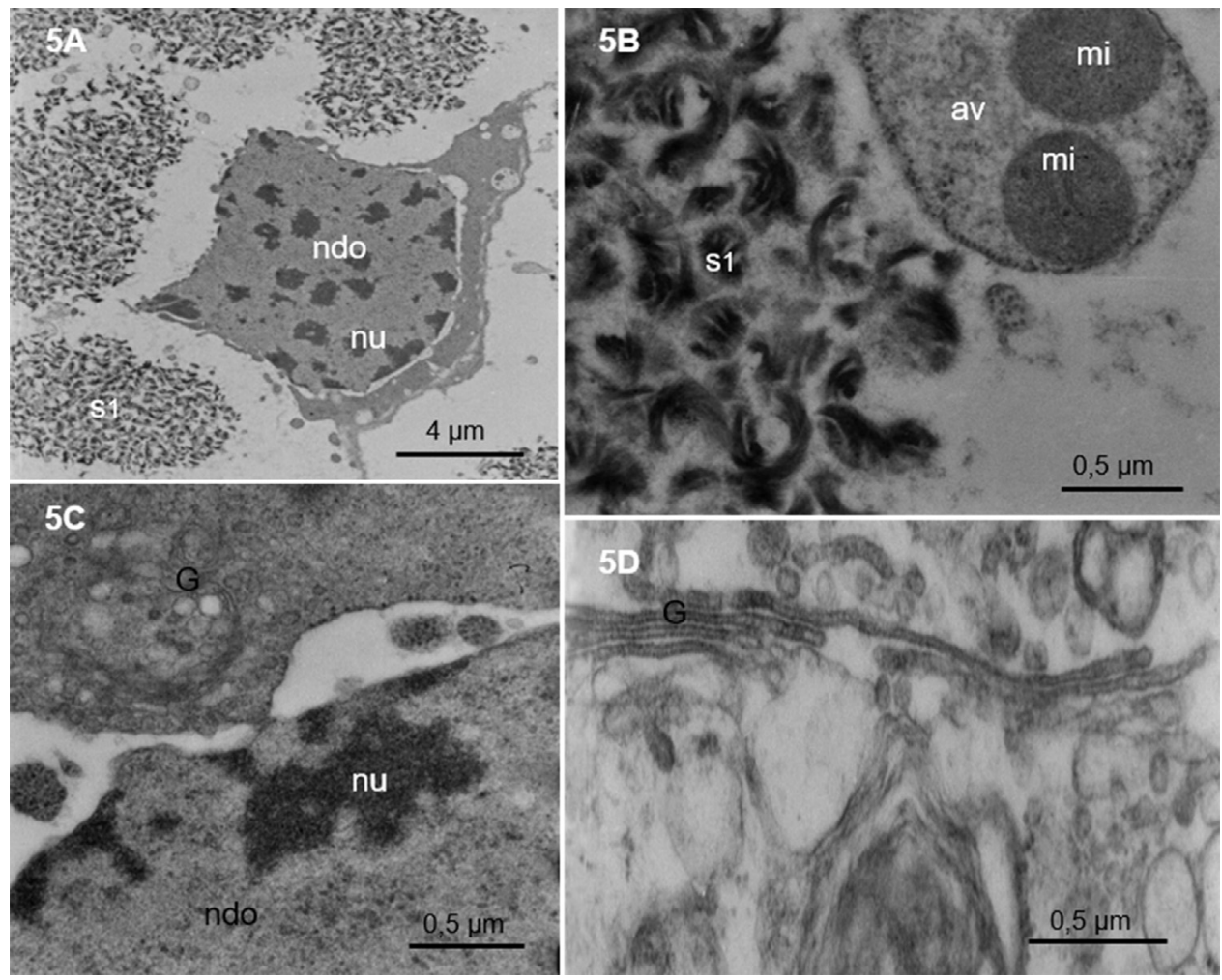

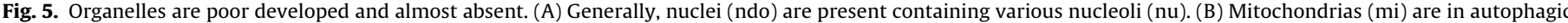
vacuole separated from secretion (s1). (C and D) Golgi apparatus were observed close to nucleus (C) and among electron transparent vesicles in cytoplasm (D).

in adhesive glands of insects (Dettner, 1983; Dettner et al., 1985). However, the dehiscent organs of Ruptitermes do not seem to fit into any of the three types of glandular cells described by Noirot and Quennedey $(1974,1991)$. Firstly, the cells of dehiscent organs are not part of the epidermis and therefore could not be classified as class I cells. Secondly, class II (oenocytes) cells with adhesive function were only found in Heteroptera (Dettner, 2010; Livingstone, 1978; Oliver et al., 1985), and dehiscent organs are not constituted by those cells according to their ultrastructure features. Thirdly, the absence of canaliculi in the cells of dehiscent organs excludes the possibility of these cells belonging to class III. Finally, in the case of dehiscent organs, the secretion is released by rupture of the abdominal wall, meaning that there is no other cell or duct that receives and discharges the secretion, as occurs in cells of class II and III, respectively. Thus, it can be concluded that the dehiscent organs can not be considered glands.

It is known that the adhesive secretions used by insects during defense are constituted by many compounds such as proteins, polysaccharides, polyphenols, lipids (including terpenes and resins), glycoproteins, proteoglycans, phenolic proteins, and phenolic polysaccharides (Ambsdorf et al., 1992; Onusseit, 2004). For example, the labial glands of soldiers of Mastotermes darwiniensis (Mastotermitidae) contain a mixture of proteins and quinones (Moore, 1968; Quennedey, 1984); the frontal glands of many species of Rhinotermitidae contain a mixture of lipids, mucopolysaccharides, proteins, and terpenes (Blum et al., 1982; Moore, 1968; Negulescu et al., 2015; Piskorski et al., 2007); the frontal gland of Nasutitermitinae (Termitidae) soldiers contains ketones, esters, alcohol, monoterpenes, diterpenes, sesquiterpenes, and monoterpene acetates, among others (Costa-Leonardo and De Salvo, 1987; Grassé, 1982; Moore, 1964; Šobotník et al., 2010a). The results of the protein analysis conducted in this study are still preliminary but indicate that the secretion of dehiscent organs of $R$. reconditus and $R$. xanthochiton is constituted mainly by proteins of high molecular weight ( $200 \mathrm{kDa})$. Other studies have shown that the proteins present in adhesive secretions have molecular weights ranging from $500 \mathrm{kDa}$ to $8 \mathrm{kDa}$, although most of the peptides are below $300 \mathrm{kDa}$ (Gnatzy et al., 2004; Jin et al., 2006; Li et al., 2008). Although much work has been done to determine the chemical composition of the defensive glands, as such frontal gland secretion of termites, the protein components of the secretions is relatively overlooked (Negulescu et al., 2015). The crystal gland of $N$. taracua produces copper-rich enzyme BP76 with a molecular weight of $76 \mathrm{kDa}$ that participate in the oxidation of hydroquinones from salivary glands to benzoquinones (Bourguignon et al., 2015b; Šobotník et al., 2012). A recent research (Negulescu et al., 2015) detailed the protein TFP4 which is the first protein cloned and characterized from the frontal defense gland secretion of termite soldiers of Coptotermes formosanus and only the fourth protein from the order Isoptera (Da Silva et al., 2003; Jeng et al., 2011, 2012; Khademi et al., 2002).

Relative to the results of the present study, we formulate two hypotheses about the origin and development of dehiscent organs:

\subsection{First hypothesis: dehiscent organs originate from fat body that produces the defensive compounds}

This hypothesis is based on the fact that larvae were examined, and fat body cells were found at the place where it should be the dehiscent organ. Furthermore, organelles were rare. The results indicate that secretion was produced before foraging phase. Also, as already stated here, dehiscent organs have no gland characteristics. The dehiscent organs developed in foraging workers may be a specialized fat body that was active when workers were younger.

The fat body of insects is a metabolic center and a tissue that stores nutritional reserves (Arrese and Soulages, 2010; Locke, 1984). Termite fat body presents three different types of cells: adipocytes, urocytes and mycetocytes (Costa-Leonardo et al., 2013). 

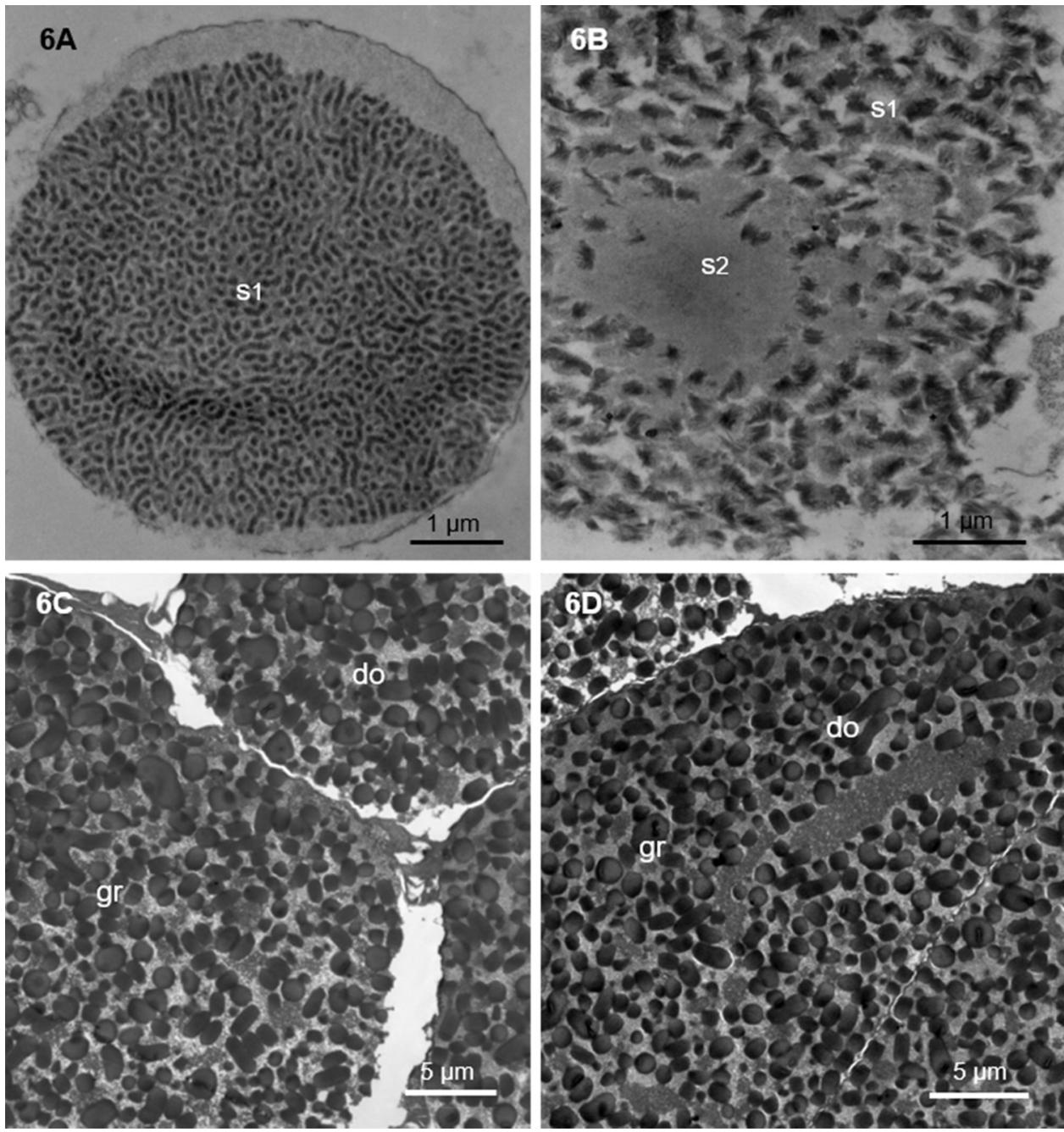

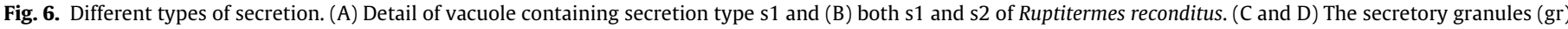
of dehiscent organs (do) of Ruptitermes pitan are electron-dense and distributed throughout the cytoplasm.

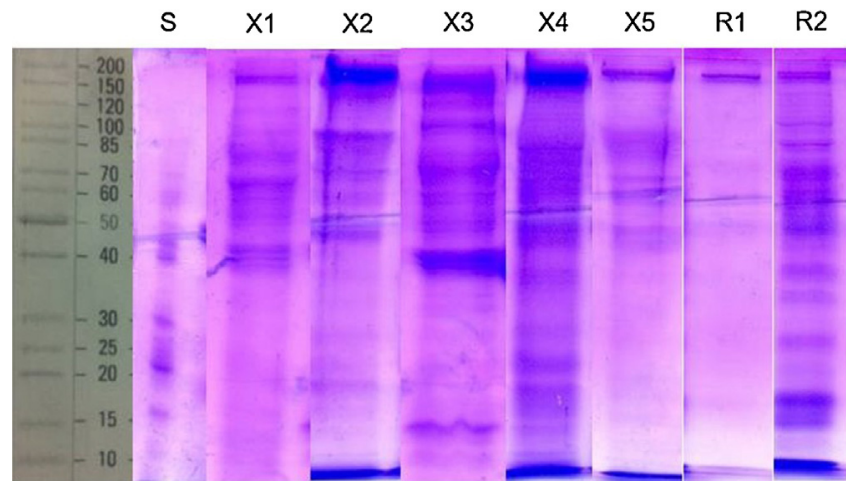

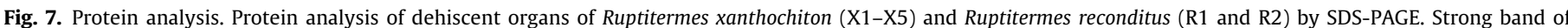

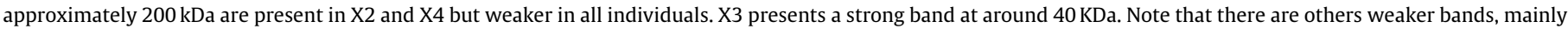
in R2. $\mathrm{S}=$ standard.

The quantity and quality of the substances accumulated in the fat body may change in accordance with the functional state of the organism. Physiologic and endocrine changes in different life stages of insects influence the metabolic functions of the fat body and, consequentially, its cytological appearance (Costa-Leonardo et al., 2013; Paes-de-Oliveira et al., 2013; Poiani and Cruz-Landim, 2012; Šobotník et al., 2006). Similar to the dehiscent organs, the fat body consists of units (lobes) surrounded by a connective tissue membrane, and cytoplasm containing large vacuoles with granular content (Costa-Leonardo et al., 2013; Šobotník et al., 2006). Both the lipid droplets and electron-dense material converge into these large vacuoles in the fat body of termites (Šobotník et al., 2006). Since there are similarities between the ultrastructure of fat body cells and that of dehiscent organ cells, we suggest that the dehis- 
cent organs might be modified fat body that produced a defensive secretion in young workers, and progressively accumulates this secretion. Thus, the vacuoles gradually expand in order to accumulate compounds that may be used by workers when they start foraging. Because adipocytes are the basic cell of the fat body, and besides storing glycogen, proteins, and lipids, these cells synthesize several types of proteins (Keeley, 1985; Price, 1973), it is likely that they are the type of fat body cell that originates the dehiscent organ.

Scanning confocal microscopy evidenced the absence of membranous organelles and transmission electron microscopy showed poor developed and rare organelles or other cellular structures, except nuclei. Similarly, Poiani and Cruz-Landim (2009) verified that cells of cephalic salivary glands of old workers of the eusocial bee Scaptotrigona postica did not contain organelles since, in that phase of life, they are just storing glandular compounds. This suggests that the developmental stage of dehiscent organs might be equally related to the age or life phase of termite workers. The workers of Ruptitermes used in this study were collected while foraging and results showed that their dehiscent organs were just accumulating secretion.

\subsection{Second hypothesis: dehiscent organs originate from fat body that not produces but absorb precursors of defensive compounds from food}

This hypothesis is based on fact that Ruptitermes are litter-feeding termites that cut and transport small pieces of decomposing leaves and small seeds, which were stored in their subterranean galleries (Lima and Costa-Leonardo, 2007). These may be the food sources of unknown compounds that constitute the secretion in their dehiscent organs. Some compounds of this specific food should reach the hemolymph and later be arrested by the mortal fat body of the termites workers.

It has been shown that the milkweed bug Oncopeltus fasciatus (Hemiptera) is capable of absorbing compounds (cardenolides) from plants, and use them to their defense system due to the permeability of these compounds in their guts. Such compounds subsequently have been accumulated in a dorsolateral space that is considered a specialized organ (Scudder and Meredith, 1982a). Thus, the production of defensive compounds is, in this case, a result of feeding. Defensive substances can also be accumulated in the cuticle and fat body cells because tissues and organs need to be protected or immunezed to the effects of defensive compounds absorbed from food (Duffey and Scudder, 1974; Duffey et al., 1978). The $O$. fasciatus has a modified integument that is constituted of an epidermal double layer, and the inner layer forms the dorsolateral space that acts as a storage compartment of cardenolides (Scudder et al., 1986). In this species, there are weak areas in the cuticle located on both sides of the thorax and abdomen that, if disrupted upon enemy attack, lead to the release of the secretion containing cardenolides (Scudder and Meredith, 1982b; Scudder et al., 1986). A similar process seems to occur in the Ruptitermes defense system as the rupture of the cuticle releases not just the defensive compounds but the whole organ.

The most of Neotropical Apicotermitinae are humivorous and only Ruptitermes are litter-feeding termites. According to Sands (1972), humivorous and litter-feeding, both termites, secondarily lost soldiers. Nevertheless, the soil-feeding and living underground nesting probably reduce vulnerability of humivorous termites, which not occurs with the litter-feeding Ruptitermes that feeds in the open on surface litter, which increases the risks of predation. This vulnerability enabled the development of alternative defensive strategies (Noirot and Darlington, 2000; Sands, 1982; Šobotník et al., 2010b).
In conclusion, the cells that compose the dehiscent organs of Ruptitermes termites do not fit into the classification proposed by Noirot and Quennedey $(1974,1991)$, and seem quite different from the exocrine gland cells of termites and other insects. We hypothesize that the dehiscent organs analyzed, which were taken from workers who were foraging (theoretically older), may have originated from cells of the fat body that accumulated defense material either, (a) produced during younger developmental stages, or (b) absorbed from food sources available in hemolymph. A preliminary protein analysis showed that the defensive compounds stored in the dehiscent organs of Ruptitermes include proteins of high molecular weight, similar to what has been found in the adhesive secretions of other termites (Jin et al., 2006; Li et al., 2008).

\section{Acknowledgments}

The authors would like to thank the financial support from Conselho Nacional de Desenvolvimento Científico e Tecnológico-CNPq, Process no. 150015/2013-5. We also thanks João Paulo L. F. Cairo, Lara T. Laranjo, Luiza H. Bueno da Silva and Vanelize Janei for their technical assistance.

\section{References}

Acioli, A.N.S., Constantino, R., 2015. A taxonomic revision of the neotropical termite genus Ruptitermes (Isoptera, Termitidae, Apicotermitinae). Zootaxa 4032, 451-492

Ahmad, M., 1976. The soldierless termite genera of the Oriental region, with a note on their phylogeny (Isoptera: Termitidae). Pak. J. Zool. 8, 105-123.

Ambsdorf, J., Mieth, A., Peter, M.G., 1992. Strategien Und Techniken Des Klebstoffeinsatzes in Der Natur-anregungen Für Die Technik-:Studie im Auftrag des Ministeriums für Natur Umwelt und Landesentwicklung des Landes Schleswig-Holstein. Selbstverlag, Kiel.

Arrese, E.L., Soulages, J.L., 2010. Insect fat body: energy, metabolism, and regulation. Annu. Rev. Entomol. 55, 2017-2225.

Blum, M.S., Jones, T.H., Howard, D.F., Overal, W.L., 1982. Biochemistry of termite defenses: Coptotermes, Rhinotermes and Cornitermes species. Comp. Biochem. Physiol. 71B, 731-733.

Boomsma, J.J., 2009. Lifetime monogamy and the evolution of eusociality. Philos Trans. R. Soc. Lond. B Biol. Sci. 364, 3191-3207.

Bordereau, C., Robert, A., Van Tuyen, V., Peppuy, A., 1997. Suicidal defensive behavior by frontal gland dehiscence in Globitermes sulphureus Haviland soldiers (Isoptera). Insectes Soc. 44, 289-296.

Bourguignon, T., Šobotník, J., Dahlsjö, C.A.L., Roisin, Y., 2015a. The soldierless Apicotermitinae: insights into a poorly known and ecologically dominant tropical taxon. Insectes Soc., 1-12.

Bourguignon, T., Šobotník, J., Brabcová, J., Sillam-Dussès, D., Buček, A., Krasulová, J., Vytisková, B., Demianová, Z., Mareš, M., Roisin, Y., Vogel, H., 2015b. Molecular mechanism of the two-component suicidal weapon of Neocapritermes taracua old workers. Mol. Biol. Evol., http://dx.doi.org/10.1093/molbev/msv273, Online.

Costa-Leonardo, A.M., 2004. A new interpretation of the defense glands of Neotropical Ruptitermes (Isoptera, Termitidae, Apicotermitinae). Sociobiology 44, 391-402.

Costa-Leonardo, A.M., Kitayama, K., 1991. Frontal gland dehiscence in the Brazilian termite Serritermes serrifer (Isoptera: Serritermitidae). Sociobiology 19, 333-338.

Costa-Leonardo, A.M., De Salvo, C.R., 1987. A comparative study of the frontal glands in three species of Brazilian termite soldiers (Isoptera, Termitidae). Rev. Bras. Entomol. 31, 465-471.

Costa-Leonardo, A.M., Laranjo, L.T., Janei, V., Haifig, I., 2013. The fat body of termites: functions and stored materials. J. Insect Physiol. 59, 577-587.

Da Silva, P., Jouvensal, L., Lamberty, M., Bulet, P., Caille, A., Vovelle, F., 2003. Solution structure of termicin, an antimicrobial peptide from the termite Pseudacanthotermes spiniger. Protein Sci. 12, 438-446.

Deligne, J., Quennedey, A., Blum, M.S., 1981. The enemies and defense mechanisms of termites. In: Hermann, H.R. (Ed.), Social Insects. Academic, New York, pp. $1-76$.

Dettner, K., 1983. Defensive secretions and exocrine glands in free-living staphylinid beetles-their bearing on phylogeny (Coleoptera: Staphylinidae). Biochem. Syst. Ecol. 21, 143-162.

Dettner, K., 2010. Insekten als Nahrungsquelle, Abwehrmechanismen. In: Dettner, K., Peters, W. (Eds.), Lehrbuch der Entomologie. Spektrum Akademischer Verlag, Heidelberg, pp. 555-559.

Dettner, K., Schwinger, G., Wunderle, P. 1985. Sticky secretion from two pairs of defensive glands of the rove beetle Deleaster dichrous (Grav.) (Coleoptera: Staphylinidae). Gland morphology, chemical constituints, defensive functions, and chemotaxonomy. J. Chem. Ecol. 11, 859-883. 
Duffey, S.S., Scudder, G.G.E., 1974. Cardiac glycosides in Oncopeltus fasciatus (Dallas). I. The uptake and distribution of natural cardenolides in the body. Can. J. Zool. 52, 283-290.

Duffey, S.S., Blum, M.S., Isman, M., Scudder, G.G.E., 1978. Cardiac glycosides: physical system for their sequestration by the milkweed bug. J. Insect Physiol. 24, 639-645.

Fontes, L.R., 1992. Key to the genera of new world Apicotermitinae (Isoptera: Termitidae). In: Quintera, D., Aiello, A. (Eds.), Insect of Panama and Mesamerica. Oxford University Press, New York, pp. 242-248.

Gnatzy, W., Voknandt, W., Schulz, S., 2004. Dufour gland of the digger wasp Liris niger structure and developmental and biochemical aspects. Cell Tissue Res. 315, 125-138.

Grassé, P.P., 1982. Termitologia. In: Anatomie, physiologie, biologie, systématique des termites. Masson, Paris.

Jeng, W.-Y., Wang, N.-C., Lin, M.-H., Lin, C.-T., Liaw, Y.-C., Chang, W.-J., Liu, C.L. Liang, P.H., wang, A.H., 2011. Structural and functional analysis of three $\beta$-glucosidases from bacterium Clostridium cellulovorans, fungus Trichoderma reesei and termite Neotermes koshunensis. J. Struct. Biol. 173, 46-56.

Jeng, W.Y., Wang, N.C., Lin, C.T., Chang, W.J., Liu, C.I., Wang, A.H., 2012. High-resolution structures of Neotermes koshunensis beta-glucosidase mutants provide insights into the catalytic mechanism and the synthesis of glucoconjugates. Acta Crystallogr. D Biol. Crystallogr. 68, 829-838.

Jin, Y.X., Jiang, Y.H., Xu, M.K., 2006. Proteome analysis of the silkworm (Bombyx mori L.) colleterial gland during different development stages. Arch. Insect Biochem. Physiol 61, 42-50.

Keeley, L.L., 1985. Physiology and biochemistry of the fat body. In: Kerkut, G.A., Gilbert, L.I. (Eds.), Comprehensive Insect Physiology, Biochemistry and Pharmacology. Pergamon Press, Oxford, pp. 211-248.

Khademi, S., Guarino, L.A., Watanabe, H., Tokuda, G., Meyer, E.F., 2002. Structure of an endoglucanase from termite, Nasutitermes takasagoensis. Acta Crystallogr. D Biol. Crystallogr. 58, 653-659.

Li, D., Huson, M.G., Graham, L.D., 2008. Proteinaceous adhesive secretions from insects, and in particular the egg attachment glue of Opodiphthera sp. moths. Arch. Insect Biochem. Physiol. 69, 85-105.

Lima, J.T., Costa-Leonardo, A.M., 2007. Recursos alimentares explorados pelos cupins (Insecta: Isoptera). Biota Neotrop. 7, 243-250.

Livingstone, D., 1978. On the body outgrowths and the phenomenon of sweatimg in the nymphal instars of Tingidae (Hemiptera: Heteroptera). J. Nat. Hist. 12, 377-394.

Locke, M., 1984. The structure and development of the vacuolar system in the fat body of insects. In: King, R.C., Akai, H. (Eds.), Insect Ultrastructure. Plenum Press, New York, pp. 151-197.

Maschwitz, U., Jander, R., Burkhardt, D., 1972. Wehsubstanzen und wehrverhalten der termite Macrotermes carbonarius. J. Insect Physiol. 18, 1715-1720.

Mathews, A.G.A., 1977. Studies on termites from the Mato Grosso State, Brazil. Academia Brasileira de Ciências, Rio de Janeiro.

Mill, A.E., 1984. Exploding termites -an unusual defensive behaviour. Entomol. Mon. Mag. 120, 179-183.

Miller, L.R., 1984. Invasitermes, a new genus of soldierless termites from northern Australia (Isoptera: Termitidae). J. Aust. Entomol. Soc. 23, 33-37.

Moore, B.P., 1968. Studies on the chemical composition and function of the cephalic gland secretion in Australian termites. J. Insect Physiol. 14, 33-39.

Moore, I., 1964. A new key to the subfamilies of the nearctic Staphylinidae and notes on their classification. Coleopterists Bull. 18, 83-91.

Negulescu, H., Guo, Y., Garner, T.P., Goodwin, O.Y., Henderson, G., Laine, R.A., Macnaughtan, M.A. 2015. A kazal-type serine protease inhibitor from the defense gland secretion of the subterranean termite Coptotermes formosanus Shiraki. PLoS One 10 (5), e0125376.

Noirot, C., Darlington, J.P.E.C., 2000. Termite nests: architecture, regulation and defence. In: Abe, T., Bignell, D.E., Higashi, M. (Eds.), Termites: Evolution, Sociality, Symbioses, Ecology. Kluver Academic, London, pp. 121-139.

Noirot, C., Quennedey, A., 1974. Fine structure of insect epidermal glands. Annu. Rev. Entomol. 19,61-80.
Noirot, C., Quennedey, A., 1991. Gland, glands cells, glandular units: some comments on terminology and classification. Ann. Soc. Entomol. Fr. 27, 123-128.

Oliver, J.E., Neal, J.W., Lusby, W.R., Aldrich, J.R., Kochansky, J.P., 1985. Novel components from secretory hairs of azalea lace bug Stephanitis pyrioides (Hemiptera: Tingidae). J. Chem. Ecol. 11, 1223-1228.

Onusseit, H., 2004. Klebstoffe der Natur. Biol. Unserer Zeit 34, 307-314.

Paes-de-Oliveira, V.T., Berger, B., Poiani, S.B., Cruz-Landim, C., 2013. Effects of treatment of the fat body trophocytes of Melipona quadrifasciata anthidioides nurse workers and virgin queens in culture by juvenile hormone III and ecdysterone (20-HE). Microsc. Res. Tech. 76, 20-27.

Pasteels, J.M., Bordereau, C., 1998. Releaser pheromones in termites. In: Vander Meer, R.K., Breed, M.D., Espelie, K.E., Winston, M.L. (Eds.), Pheromone Communication in Social Insects: Ants, Wasps, Bees and Termites. Westview Press, Boulder, pp. 193-215.

Piskorski, R., Hanus, R., Vašíčková, S., Cvačka, J., Šobotiník, J., Svatoš, A., Valterová, I., 2007. Nitroalkenes and sesquiterpene hydrocarbons from the frontal gland of three Prorhinotermes termite species. J. Chem. Ecol. 33, 1787-1794.

Poiani, S.B., Cruz-Landim, C., 2009. Cephalic salivary gland ultrastructure of worker and queen eusocial bees (Hymenoptera, Apidae). Anim. Biol. 59, 299-311.

Poiani, S.B., Cruz-Landim, C., 2012. Storaged products and presence of acid phosphatase in fat body cells at pre-pupal worker stage of Apis mellifera Linnaeus, 1758 (Hymenoptera, Apidae). Micron 43, 475-478.

Price, G.M., 1973. Protein and nucleic acid metabolism in insect fat body. Biol. Rev. 48, 333-375.

Quennedey, A., 1975. Morphology of exocrine glands producing pheromones and defensive substances in subsocial and social insects. In: Proceedings of the IUSSI Symposium, (Dijon), pp. 1-21.

Quennedey, A., 1984. Morphology and ultrastructure of termite defense glands. In: Hermann, H.R. (Ed.), Defensive Mechanisms in Social Insects. Praeger, New York, pp. 151-200.

Quennedey, A., 1998. Insect epidermal gland cells: ultrastructure and morphogenesis. In: Harrison, F.W., Locke, M. (Eds.), Microscopic Anatomy of Invertebrates, vol. 11A. Wiley, New York, pp. 177-207, Insecta.

Sands, W.A., 1972. The soldierless termites of Africa (Isoptera: Termitidae). Br. Mus. Nat. Hist. Entomol. (Suppl. 18), 1-244.

Sands, W.A., 1982. Agonistic behavior of African soldierless Apicotermitinae (Isoptera: Termitidae). Sociobiology 7, 61-72.

Scudder, G.G.E., Meredith, J., 1982a. The permeability of the midgut of three species to cardiac glycosides. J. Insect Physiol. 28, 689-694.

Scudder, G.G.E., Meredith, J., 1982b. Morphological basis of cardiac glycoside sequestration by Oncopeltus fasciatus (Dallas) (Hemiptera, Lygaeidae). Zoomorphology 99, 87-101.

Scudder, G.G.E., Moore, L.V., Isman, M.B., 1986. Sequestration of cardenolids in Oncopeltus fasciatus: Morphological and physiological adaptations. J. Chem. Ecol. 12, 1171-1187.

Silvestri, F., 1901. Nota Preliminare sui Termitidi Sud-Americani. Boll. Mus. Zool. Anat. Comp. Torino 16, 1-8.

Šobotník, J., Weyda, F., Hanus, R., Cvačka, J., Nebesářová, J., 2006. Fat body of Prorhinotermes simplex (Isoptera: Rhinotermitidae): Ultrastructure, inter-caste differences and lipid composition. Micron 37, 648-656.

Šobotník, J., Hanus, R., Jirošová, A., 2010a. Chemical warfare in termites. J. Insect Physiol. 56, 1012-1021.

Šobotník, J., Sillam-Dussès, D., Weyda, F., Dejean, A., Roisin, Y., Hanus, R. Bourguignon, T., 2010b. The frontal gland in workers of Neotropical soldierless termites. Naturwissenschaften 97, 495-503.

Šobotník, J., Bourguignon, T., Hanus, R., Demianová, Z., Pytelková, J., Mareš, M., Foltynová, P., Preisler, J., Cvačka, J., Roisin, Y., 2012. Explosive backpacks in old termites workers. Science 337, 436.

Šobotník, J., Kutalová, K., Vytisková, B., Roisin, Y., Bourguignon, T., 2014. Age-dependent changes in ultrastructure of the defensive glands of Neocapritermes taracua workers (Isoptera, Termitidae). Arthropod Struct. Dev. 43, 205-210. 